\title{
Of Cultural Backlash and Economic Insecurity in the 2016 American Presidential Election
}

\author{
Paul Christopher Manuel
}

\section{Abstract}

Given the strong support of evangelical Christian voters to Donald Trump's 2016 presidential campaign, many have wondered how, exactly, the pro-religious Trump campaign managed to prevail in an increasingly secular society. This article considers two conceptual models, offered by Ronald Inglehart and Pippa Norris, to bring some understanding to the Trump phenomena: the economic insecurity perspective and the cultural backlash thesis. Each will be considered in terms of three related and interlocking sets of issue clusters: the overall secular direction of the American population, the rural-urban cleavage, and empathy for the forgotten man and woman.

Keywords: Donald Trump. Cultural backlash. Economic insecurity. Rural-urban cleavage. Empathy. Forgotten man and woman.

\section{Introduction}

In the sixty-seven years since the election of John F. Kennedy, America's first and thus far only Roman Catholic president, there has been a steady decline of religious affiliation among Americans. And yet, given the strong support of evangelical Christian voters to Donald Trump's 2016 presidential campaign, many have wondered how, exactly, the pro-religious Trump campaign managed to prevail in an increasingly secular society. ${ }^{2}$ That is not an easy question to answer.

1 Professor na American University, Washington D.C. (EUA). Bolsista de investigação no Berkley Center for Religion, Peace and World Affairs at Georgetown University, Washington D.C.

2 The 2016 Republican Platform promises to defend religious liberty and traditional values, at <https://prod-static-ngop-pbl.s3.amazonaws.com/media/documents/DRAFT_I2_FINAL[I]-ben_1468872234.pdf>. In an insightful article following the election, BBC reporter Anthony Zurcher usefully identifies five key factors to the Trump victory. First, the high turn-out of the pro-Trump, so-called "white wave" - working-class, low educated, white people - played a role. Second, the "Teflon Donald" effect enabled him overcome a series of controversies which would have probably ended other presidential campaigns. Third, Trump's anti-Washington elite outsider insurgency approach appealed to many voters. Fourth, the surprise announcement by FBI director James 
Ronald Inglehart and Pippa Norris (2016, p. 1) have recently offered two conceptual models aimed to bring some understanding to the Trump phenomena, as well as the success of populist movements elsewhere: the economic insecurity perspective emphasizes the consequences of profound changes transforming the workforce and society in post-industrial economies, and the cultural backlash thesis suggests the Trump victory may be best understood as a reaction against elite-driven secularization and progressive value change. ${ }^{3}$ This article will consider both of these explanations in terms of three related and interlocking sets of issue clusters: the overall secular direction of the American population, the rural-urban cleavage, and empathy for the forgotten man and woman. We will examine each of these in turn.

\section{The Secular Direction of the American Population}

At the Values Voters Summit at the Omni Shoreham Hotel in Washington, D.C. on September 9, 2016, Donald Trump promised that, if elected, "it will be our faith in God, in his teachings, in each other that will lead us back to unity". However, per recent data by the Gallup polling agency, Americans appear to be less religious in 2016 than was the case earlier. They may be moving in either a "secular" direction, or at least in a "non-affiliated" religious world view.

Let's take a look at the secular direction of American society. Table 1 details the religious preference of Americans from 1956 to 2016. The selfidentified Christian population, including Protestant and Roman Catholic, has dropped 26 points over the last sixty years; from 96 percent of the total American population in 1956 to 69 percent in 2016. That significant drop

Comey a few weeks before the election that the agency reopened its investigation into Hillary Clinton's private email server cast a shadow over her authenticity and truthfulness. Fifth. Trump's unconventional political instincts were spot-on, including holding massive rallies in the democratic strongholds of Michigan. Wisconsin and Pennsylvania. Other reasons offered for the Trump victory include a poorly-run Clinton campaign, and possible Russian interference. Combined, these provide insight on what happened. See <http://www.bbc.com/ news/election-us-2016-37918303>.

3 This paper was also presented at the roundtable "Rage against the Machine: Populist Politics in the U.S., Europe and Latin America", 2 September 2016, at the annual meeting of the American Political Science Association, Philadelphia. Inglehart and Norris find more convincing data to support the cultural backlash theory, but both models hold explanatory power. The electoral outcome certainly ran contrary to the expectations of most academics and professional pollsters. 
implies that politics and policy formation in the United States may take a significantly more secular flavor in the future. It is true that most Americans still self-identify as Christians; it is also true that there is more religious diversity in 2016 than ever before. Those self-identifying as having "no religion" jumped 17 points in the last sixty years; from 1 percent in 1956 to 18 percent in 2016. To that point, Pew reports that "When it comes to the nation's religious identity, the biggest trend during Obama's presidency is the rise of those who claim no religion at all. Those who self-identify as atheists or agnostics, as well as those who say their religion is 'nothing in particular', now make up nearly a quarter of the U.S. adult population, up from $16 \%$ in 2007” (PEW RESEARCH CENTER, 2016b, [s. p.]). ${ }^{4}$

At the very least, we can take from these findings that America appears to be moving in a secular direction.

Table I - What is your religious preference - Protestant, Roman Catholic, Jewish, Muslim, another religion, or no religion, 1956-2016?

\begin{tabular}{|c|c|c|c|c|c|c|c|c|}
\hline & Protestant & $\begin{array}{c}\text { Christian } \\
\text { (nonspecific) }\end{array}$ & Catholic & Jewish & Mormon & Other & None & $\begin{array}{c}\text { No } \\
\text { answer }\end{array}$ \\
\hline & $\%$ & $\%$ & $\%$ & $\%$ & $\%$ & $\%$ & $\%$ & $\%$ \\
\hline 2016 & 37 & 10 & 22 & 3 & 2 & 5 & 18 & 2 \\
\hline 2006 & 49 & 6 & 22 & 2 & 2 & 5 & 12 & 2 \\
\hline 1996 & 56 & $\mathrm{n} / \mathrm{a}$ & 25 & 3 & 1 & 6 & 7 & 2 \\
\hline 1986 & 58 & $\mathrm{n} / \mathrm{a}$ & 27 & 2 & 2 & 2 & 9 & * \\
\hline 1976 & 60 & $\mathrm{n} / \mathrm{a}$ & 28 & 2 & $\mathrm{n} / \mathrm{a}$ & 3 & 6 & * \\
\hline 1966 & 67 & $\mathrm{n} / \mathrm{a}$ & 25 & 3 & $\mathrm{n} / \mathrm{a}$ & 2 & 2 & * \\
\hline 1956 & 71 & $\mathrm{n} / \mathrm{a}$ & 25 & 3 & $\mathrm{n} / \mathrm{a}$ & * & 1 & * \\
\hline
\end{tabular}

Source: Gallup (2016).

Likewise, Table 2 indicates that religion is somewhat less important in the lives of Americans today. Although the numbers were steady from 1995

4 <http://www.pewresearch.org/2017/01/10/how-america-changed-during-barack-obamas-presidency/>. 
to 2006, things changed over the last decade: nine percent more of the population in 2016 report that religion less important in their daily lives than was the case in 2006.

Table 2 - How important would you say religion is in your own life

- very important, fairly important or not very important, 1996-2016?

\begin{tabular}{ccccc}
\hline & Very important & Fairly important & Not very important & No opinion \\
\hline \multirow{2}{*}{2016} & $\%$ & $\%$ & $\%$ & $\%$ \\
2006 & 53 & 22 & 25 & 1 \\
1996 & 57 & 27 & 16 & I \\
\hline \multicolumn{5}{c}{ Source: Gallup (2016). }
\end{tabular}

Further, Table 3 indicates that 18 percent more Americans now think that religion is losing its influence in American society, from 57 percent in 2006 to 75 percent in 2016. Interestingly, as was the case in Table 2, the numbers remained steady from 1995 to 2005; the increased secular direction is more noticeable since 2006.

Table 3 - At the present time, do you think religion as a whole is increasing its influence on American life or losing its influence, 1995-2006?

\begin{tabular}{ccccc}
\hline & Increasing its influence & Losing its influence & Same (vol.) & No opinion \\
\hline & $\%$ & $\%$ & $\%$ & $\%$ \\
2016 & 22 & 75 & 1 & 2 \\
2006 & 40 & 55 & 2 & 3 \\
1995 & 37 & 57 & 3 & 3 \\
\hline
\end{tabular}

Source: Gallup (2016).

Table 4 indicates, interestingly, that there has not been much change on the actual religious practices of Americans: only five percent fewer Americans reported having attended religious services regularly 2016 than was the case in in 1996: 51 percent in 2016, and 56 percent in 1996. There has been some drop-off in religious practice, but most Americans continue to practice their faith. 
Table 4 - How often do you attend church or synagogue - every week, almost every week, about once a month, seldom or never?

\begin{tabular}{cccccc}
\hline & Every week & Almost every week & About once a month & Seldom & Never \\
\hline & $\%$ & $\%$ & $\%$ & $\%$ & $\%$ \\
2016 & 26 & 12 & 13 & 28 & 20 \\
2006 & 31 & 12 & 15 & 28 & 14 \\
1996 & 29 & 12 & 15 & 32 & 11 \\
\hline
\end{tabular}

Source: Gallup (2016).

While most Americans may still be practicing their faith, they seem to rely less on religion in 2016 than in 1995 . We can see in Table 5 that the number of people responding affirmatively that religion can solve societal problems dropped seven points, from $54 \%$ in 2016 to $61 \%$ in 1995 . That seven-point drop may indicate a slow move away from a belief in the on-going relevance of religion.

Table 5 - Do you believe that religion can answer all or most of today's problems, or that religion is largely old-fashioned and out of date?

\begin{tabular}{ccccc}
\hline & Yes, can answer & No, largely out of date & Other (vol.) & No opinion \\
\hline & $\%$ & $\%$ & $\%$ & $\%$ \\
2016 & 54 & 33 & 6 & 7 \\
2006 & 60 & 25 & 10 & 5 \\
1995 & 61 & 21 & 13 & 5 \\
\hline
\end{tabular}

Based on yearly aggregates; (vol.) = Volunteered response Source: Gallup (2016).

Similarly, Table 6 shows that Americans have less confidence in religious institutions than previously: there was a 16 point drop over the last forty years, 88 percent answered affirmatively in 1975 while only 72 percent did so in 2016. Over that same timeframe, there has been a 24 percent point move away from "great deal of confidence" in religion (44 percent in 1975 to 20 percent in 2016) to "some confidence" in religion (20 percent in 1975 to 31 percent in 2016). Conversely, those with little or no confidence in religion jumped 17 percentage points over the last forty years; from 10 percent in 1975 to 27 percent in 2016. 
Table 6 - Now I am going to read you a list of institutions in American society. Please tell me how much confidence you, yourself, have in each one - a great deal, quite a lot, some or very little? The church or organized religion

\begin{tabular}{cccccc}
\hline & Great deal & Quite a lot & Some & Very little & None (vol.) \\
\hline & $\%$ & $\%$ & $\%$ & $\%$ & $\%$ \\
2016 & 20 & 21 & 31 & 24 & 3 \\
2006 & 28 & 24 & 26 & 19 & 2 \\
1996 & 30 & 27 & 27 & 13 & 2 \\
1986 & 34 & 23 & 27 & 12 & 3 \\
1975 & 44 & 24 & 20 & 9 & 1 \\
\hline
\end{tabular}

Source: Gallup (2016).

To sum up the key findings from Gallup:

- Twenty-six percent fewer Americans self-identify as Christian in 2016 than in 1956.

- Ten percent more Americans report that religion is not very important in 2016 than in 1996.

- Eighteen percent more Americans think that religion is losing its societal influence in 2016 than in 1995.

- Five percent fewer Americans attended religious services in 2016 than 1996.

- Seven percent fewer Americans think religion can solve societal problems in 2016 than in 1995.

- Sixteen percent fewer Americans have confidence in religious institutions in 2016 than in 1975.

Religion still matters in the United States, but clearly not at the level that it once did. These findings suggest that American society is moving in a secular direction (SCHWADEL, 2012). So, how did a presidential candidate, who was strongly endorsed by the religious right, manage to prevail in an increasingly secular American society in 2016? 


\section{The Rural-Urban Cleavage in the United States}

To try to approach that question, let us briefly examine the rural-urban cleavage in the United States. Arguably, and as demonstrated in Map 1, the Clinton-Trump presidential debate ignited the old cleavage line between the secular values of a majority of the population living in the urban areas, university towns and coastal areas, and the religious values of most people living in rural areas, especially the in the south and middle parts of the country.

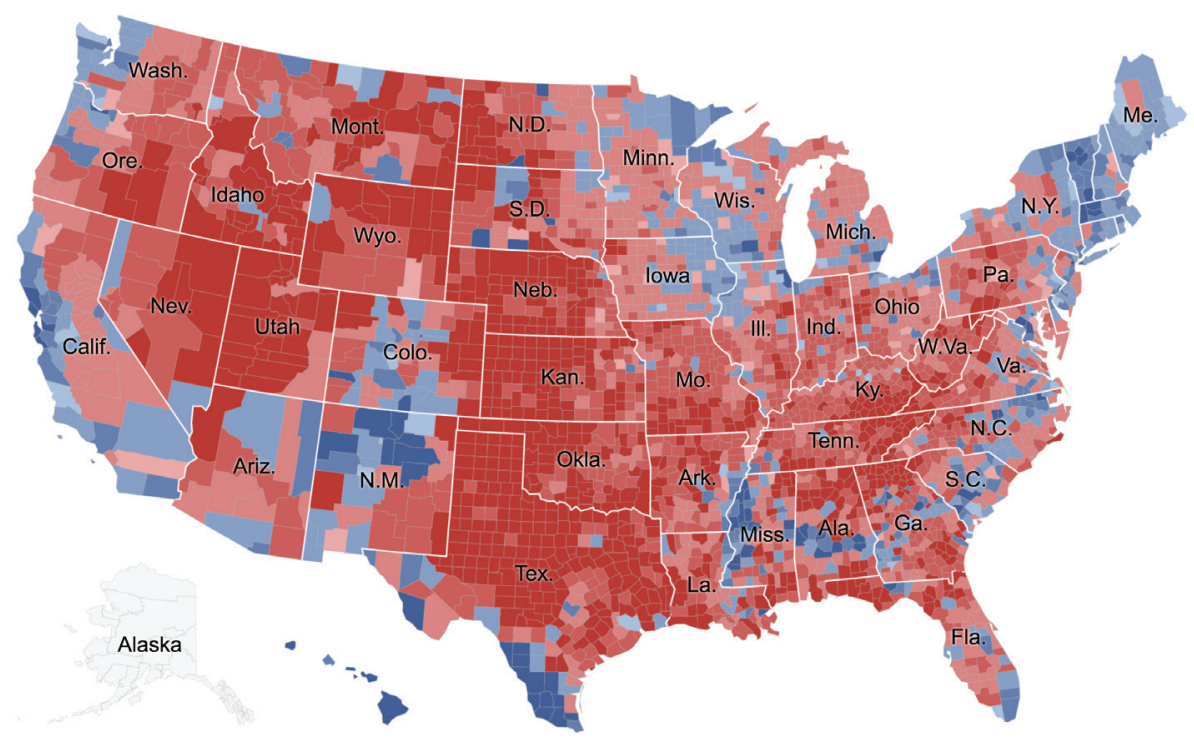

Map I - Results of the 2016 Presidential Election ${ }^{5}$

Source: Parlapiano (2016).

The country was divided between the comparatively wealthy, welleducated, and modern urban areas voting for Clinton, and those poorer, less-educated and rural areas turning out for Trump. The Trump victory could be understood as a sort of rural-cultural backlash against urban-elite secularization: if elected, as he promised to realign public policy to basic

$5<$ <http://www.nytimes.com/interactive/20I6//I/0I/upshot/many-ways-to-map-election-results.html?_r=0>. 
American religious roots (ABC NEWS, 2016). ${ }^{6}$ As such, the electoral outcome could be understood as a shift away from the progressive policies of the Obama, to perhaps into a new conservative and pro-religious era of policy making. To that point, Inglehart and Norris suggest that:

[Trump's] rejection of "political correctness» seems particularly appealing to older, religious white traditionalists who find themselves left behind by growing support in America for such issues as same-sex marriage, rights for transsexuals, gender equality for women in politics, and immigration rights [...]. These retro policies appeal deeply to those intolerant of progressive values - but this is a shrinking sector swimming against the tide of generational value change in the American electorate. (2016, p. 31).

Several interesting recent survey results by the Pew Research Center support that observation. Table 7 finds that most republican voters preferred a candidate share their religious values, but it was not important for most democrats.

Table 7 - How important is it to have a president who shares your religious beliefs?*

\begin{tabular}{lccc}
\hline & Total & $\begin{array}{c}\text { Republicans/ } \\
\text { Rep. leaning }\end{array}$ & $\begin{array}{c}\text { Democrats/ } \\
\text { Dem. leaning }\end{array}$ \\
\hline NET very/somewhat important & $\mathbf{5 1}$ & $\mathbf{6 4}$ & $\mathbf{4 1}$ \\
Very important & 27 & 33 & 22 \\
Somewhat important & 24 & 31 & 19 \\
NET not too /not at all important & $\mathbf{4 8}$ & $\mathbf{3 5}$ & $\mathbf{5 8}$ \\
Don't know & 1 & 1 & 1 \\
\hline
\end{tabular}

*Survey conducted jan. 7-14, 2016.

Source: Pew Research Center (2016a). ${ }^{7}$

6 In a particularly self-effacing moment. Trump admitted at his acceptance speech at the Republican National Convention in July, 2016, that while he appreciated the support of evangelical Christians, he was not particularly deserving of it: "At this moment, I would like to thank the evangelical and religious community because I'll tell you what, the support that they've given me, and I'm not sure I totally deserve it, has been so amazing and has had such a big reason for me being here tonight. True. So true. They have much to contribute to our politics, yet our laws prevent you from speaking your minds from your own pulpits". <http://abcnews. go.com/Politics/full-text-donald-trumps-20 /6-republican-national-convention/story?id=40786529>.

7 <http://www.pewforum.org/2016/01/27/faith-and-the-2016-campaign/>. 
Not surprisingly, Table 8 shows that Donald Trump was not considered to have a religious orientation, ranking well behind all the other candidates.

Table 8 - Percent of adults who view each candidate as religious*

\begin{tabular}{lcccccc}
\hline & Very & Somewhat & NET & Not too & Not at all & NET \\
\hline Ben Carson & $35 \%$ & $33 \%$ & $68 \%$ & $7 \%$ & $4 \%$ & $11 \%$ \\
Ted Cruz & 25 & 40 & 65 & 7 & 5 & 12 \\
Marco Rubio & 16 & 45 & 61 & 8 & 5 & 13 \\
Hillary Clinton & 10 & 38 & 48 & 22 & 22 & 43 \\
Bernie Sanders & 5 & 34 & 40 & 18 & 17 & 35 \\
Donald Trump & 5 & 25 & 30 & 22 & 37 & 60 \\
\hline
\end{tabular}

* Survey conducted jan. 7-14, 2016. Don't know/refused responses not shown. Source: Pew Research Center (2016a). ${ }^{8}$

Despite the findings in Table 7 and 8 - which logically would lead one to the conclusion that conservative white evangelical Protestant voters would choose a like-minded, religious candidate like Ben Carson or Ted Cruz - able 9 shows that $52 \%$ of those voters still considered that Trump, tied with Ben Carson, would make a "good" or a "great" president. Cruz (49\%) was also well evaluated, although another religious candidate, Marco Rubio lagged (34\%). The other candidates, perceived to be less-religious, or non-religious, including Christie (24\%), Sanders (16\%), and Clinton (15\%), all scored poorly. Among the non-religious candidates, only Trump was highly evaluated (PEW RESEARCH CENTER, 2016a). ${ }^{9}$

In a similar way, Table 9 shows that Donald Trump scored significantly better with religious voters than Hillary Clinton, even though she ranked as a more religious candidate. It appears that his promises to pursue their political agenda was much more important that their evaluation of his religious beliefs and sometimes scandalous comments about women (THE NEW YORK TIMES, 2016). ${ }^{10}$

8 <http://www.pewforum.org/2016/01/27/faith-and-the-2016-campaign/>.

9 <http://www.pewforum.org/2016/01/27/faith-and-the-2016-campaign/>.

10 <https://www.nytimes.com/20/6//0/09/us/politics/trump-women-history.html>. 
Table 9 - Percent of white evangelical Protestant registered voters evaluating the candidates*

\begin{tabular}{lcccccccc}
\hline & $\begin{array}{c}\text { NET } \\
\text { Good/ } \\
\text { great }\end{array}$ & Great & Good & Average & $\begin{array}{c}\text { NET } \\
\text { Poor/ } \\
\text { terrible }\end{array}$ & Poor & Terrible & $\begin{array}{c}\text { No } \\
\text { Opinion }\end{array}$ \\
\hline Ben Carson & $52 \%$ & $16 \%$ & $36 \%$ & $24 \%$ & $14 \%$ & $9 \%$ & $5 \%$ & $10 \%$ \\
Donald Trump & 52 & 14 & 38 & 12 & 29 & 13 & 16 & 8 \\
Ted Cruz & 49 & 12 & 37 & 27 & 13 & 8 & 6 & 10 \\
Marco Rubio & 34 & 5 & 29 & 32 & 18 & 13 & 5 & 16 \\
Chris Christie & 24 & 1 & 23 & 39 & 27 & 17 & 10 & 10 \\
Jeb Bush & 23 & 3 & 20 & 36 & 36 & 21 & 15 & 5 \\
John Kasich & 17 & 1 & 16 & 32 & 21 & 16 & 5 & 29 \\
Bernie Sanders & 16 & 4 & 13 & 19 & 50 & 20 & 29 & 14 \\
Hillary Clinton & 15 & 3 & 12 & 11 & 74 & 24 & 50 & 1 \\
\hline
\end{tabular}

*Survey conducted jan. 7-14, 2016. Based on registered voters. Source: Per Research Center (2016b).

Table 10 - Presidential vote by religious attendance*

\begin{tabular}{ccc}
\hline & Clinton & Trump \\
\hline Attend Worship Services... & $\%$ & $\%$ \\
At least once a week & 40 & 56 \\
Monthly & 46 & 49 \\
Few times a year & 48 & 47 \\
Never & 62 & 31 \\
\hline
\end{tabular}

* National Election Pool national exit polls, as reported at NBCnews.com.

Source: Pew Research Center (2016c)"1

To sum up these Pew Research findings:

- Most republican voters preferred a candidate share their religious values;

II <http://www.pewresearch.org/fact-tank/2016/I I/09/how-the-faithful-voted-a-preliminary-20 I 6-analysis/ ft_I6-II-09_relig_exitpoll_attendance/>. 
- Donald Trump was not considered to be a particularly strong religious orientation; and,

- Donald Trump scored significantly better with religious voters than Hillary Clinton.

These results indicate that something out of the ordinary was behind the evangelical support for Trump (ZURCHER, 2016)..$^{12}$ To that point, Michael Hout and Claude S. Fischer have (2014, p. 444) argued that "[...] religious preferences are now as much an outcome of political identification as political identification once was an expression of religious tradition and political mobilization". So, if religious political preferences in contemporary American society are now conceived as outcomes of political identification rather than an expression of religious tradition, then the religious support for Donald Trump makes some more sense. There may have been an electoral calculation on behalf of religious voters that Trump - idely considered to be a non-religious actor - was better equipped to advance their political agenda than would have been the case with more religious-affiliated candidates like Ted Cruz or Ben Carlson. ${ }^{13}$ Also, the fact that Hillary Clinton was considered to be more religious than Donald Trump had no bearing on their vote, probably because of the progressive policies she proposed. ${ }^{14}$

There is also an institutional dimension to the American presidential election. The 2016 election enabled the people in a majority of states to have the final say on questions of public policy. Although Hillary Clinton prevailed in the total popular vote by 2.864 .974 , most of this margin of victory was

12 Of note, the overall evangelical voting pattern in 2016 resembled the 2012 election. For example, in 2016, Donald Trump won 58 percent of the evangelical vote, compared with 57 percent won by Mitt Romney in 2012. Trump, with 52 percent of the Catholic vote, did outpaced Romney's 201248 percent total. But, even though the surprising support of evangelicals for Trump was widely discussed; their actual voting total is almost the same in the last two elections, <http://www.bbc.com/news/election-us-2016-379/8303>.

13 Hout and Fischer (2014, p. 444) argue that "[...] for decades Americans' religious identifications were solid expressions of self that social scientists used to predict many other important facts of social life [...] cultural and political conflicts since the 1960s have shaken those solid expressions".

14 To that point, see Choma and Hanoch (2016). They argue that right-wing authoritarianism (RWA) and social dominance orientation (SDO) predicted Trump support and voting intentions for Clinton. They also found that higher RWA and SDO and lower cognitive ability predicted more favorable attitudes of Trump, greater intentions to vote for Trump, and lower intentions to vote for Clinton. Rothwell and Diego-Rosell (2016) of the Gallup polling organization found similar results. 
accumulated by a huge victory in California, where she won by 4.269 .978 votes (THE NEW YORK TIMES, 2017). ${ }^{15}$

The framers of the constitutional system in the United States feared the danger of mob rule, and carefully designed the presidential election system to balance geography against population. So, it is not the case that American had a single national election for president. If that were how things worked in the United States, Hillary Clinton would have been elected president. To the contrary, there were fifty simultaneous state elections held to choose electors to vote for the president, and Donald Trump prevailed in thirty of the fifty state elections. He won the electoral college vote by a final tally of 304 to 227 .

The core American constitutional principal that governmental legitimacy requires a mandate of a majority of voters in a majority of the states was upheld - and those populations from the middle of the country seemingly voted against the previously dominant cultural policies of the liberal, secular elite based on the east and west coasts during the Obama presidency.

\section{Empathy for the Forgotten Man and Woman}

There is also the issue of empathy for the forgotten man and woman. Astonishingly, Donald Trump, the thrice-married New York City billionaire, managed to connect with traditional democratic non-college educated working class voters in a powerful way. He promised to institute policies predicated on economic nationalism, to stop the flow of jobs overseas. He also promised to fight terrorism, to make the country safe. At the Republican national convention, he notably promised that, "I am going to bring back our jobs to Ohio and Pennsylvania and New York and Michigan and all of America and I am not going to let companies move to other countries, firing their employees along the way without consequence. Not going to happen anymore! (ABC NEWS, 2016). ${ }^{16}$

15 <http://www.nytimes.com/elections/results/president>. Clinton won the national popular vote by 65.844 .610 votes (48,1\%) to 62.979 .636 votes (46\%). In California, she won 8.753 .788 (61,5\%) to 4.483 .810 (31,5\%), and in New York State 4.547 .218 (59\%) to 2.814.346 (36,5\%).

16 <http://abcnews.go.com/Politics/full-text-donald-trumps-2016-republican-national-convention/ story?id=40786529>. 
Clearly, the unorthodox anti-establishment and populist leadership style of Donald Trump heavily influenced the 2016 presidential election (POSNER, 2017). Even though he has lived a wealthy and secular life, Trump seemingly managed to touch the fate of the common man around the questions of economic insecurity, unemployment, and terrorism. Some studies have indicated that economic distress may not have been an important factor in the final voting decision, but perhaps the very sympathy given by Trump to the "forgotten man and woman" was enough to bring in voters in the rust belt states of Michigan, Pennsylvania, and Wisconsin (ROTHWELL; DIEGO-ROSELL, 2016). His promise to "Make America Great Again," first used by Ronald Regan during his 1980 campaign (CAMPBELL, 2015) 17 whether or not it can be accomplished - may have helped him connect to these voters. Another one of his promises, to "Make America Safe Again," 18 may have also helped him address a generalized social anxiety and feeling of helplessness given the threat of terrorism.

\section{Conclusion}

Both the "economic insecurity perspective" and "the cultural backlash thesis" provide insight to the complex dynamic behind Trump's victory. On the one hand, the focus of the cultural backlash thesis on a popular reaction against elite-driven secularization and progressive value change can be seen in the evangelical support for Trump. On the other hand, to the degree that the economic insecurity perspective emphasizes the consequences of profound changes transforming the workforce and society in post-industrial economies, it resonates with the Trump campaign focus on the forgotten man and woman. Similarly, Hout and Fischer (2014, p. 444) contention that religious political preferences in contemporary American society are better conceived as outcomes of political identification rather than an expression of religious tradition is another useful way to comprehend the Trump victory. It is early, but one outstanding question is whether the Trump victory is simply a temporary populist-religious breakthrough against the elite, secular and

17 <http://www.businessinsider.com/donald-trump-trademarked-make-america-great-again-2015-5>.

18 <https://www.donaldjtrump.com/press-releases/donald-trumps-plan-to-defeat-isis-and-make-americasafe-again>. 
progressive policies of the Obama-era, or whether it represents something completely new.

\section{References}

ABC NEWS. Donald Trump's 2016 Republican National Convention Speech. 22 jul. 2016. Disponível em: <http://abcnews.go.com/Politics/full-text-donald-trumps-2016republican-national-convention/story?id=40786529>. Access in: 10 june 2017.

CAMPBELL, C. Donald Trump trademarked a Ronald Reagan slogan and would like to stop other Republicans from using it. 12 may 2015. Disponível em: <http://www. businessinsider.com/donald-trump-trademarked-make-america-great-again-2015-5>. Access in: 10 june 2017.

CHOMA, B. L.; HANOCH, Y. Cognitive ability and authoritarianism: Understanding support for Trump and Clinton. Personality and Individual Differences, s/n, p. 1-5, 2016.

DONALD J. TRUMP. 2017. Disponivel em: <https://www.donaldjtrump.com/press-releases/ donald-trumps-plan-to-defeat-isis-and-make-america-safe-again>. Access in: 10 june 2017.

FUNK, C.; SMITH, G. Nones on the rise: One-in-five adults have no religious affiliation. In: PEW FORUM ON RELIGION AND PUBLIC LIFE, 2012, Washington. Annals... Washington: Pew Research Center, 2012.

GALLUP. Religion. 2016. Disponível em: <http://www.gallup.com/poll/1690/religion. aspx>. Access in: 10 june 2017.

GELMAN, A.; HILL, J. Data analysis using regression and multilevel/hierarchical models. Cambridge: Cambridge University Press, 2006.

HOUT, M.; FISCHER, C. S. Explaining why more Americans have no religious preference: Political backlash and generational succession, 1987-2012. Sociological Science, v. 1, n. 9, p. 423-47, 2014.

INGLEHART, Ronald. Inequality and Modernization: Why Equality Is Likely to Make a Comeback. Foreign Affairs, 95, 2016.

INGLEHART, R.; NORRIS, P. Trump, Brexit, and the Rise of Populism: Economic HaveNots and Cultural Backlash. Faculty Research Working Paper Series, Harvard Kennedy School, 2016. Disponivel em: <https://research.hks.harvard.edu/publications/getFile. aspx? $\mathrm{Id}=1401>$. Access in: 10 june 2017. 
OWENS, L. A.; PEDULLA, D. S. Material welfare and changing political preferences: The case of support for redistributive social policies. Social Forces, v. 92, n. 3, p. 1087-1113, 2014.

PARLAPIANO, A. There Are Many Ways to Map Election Results. We've Tried Most of Them. nov. 2016. The New York Times. Disponível em: <https:/www.nytimes.com/ interactive/2016/11/01/upshot/many-ways-to-map-election-results.html?_r=0>. Access in: 10 june 2017.

PEW RESEARCH CENTER. Faith and the 2016 Campaign. GOP candidates seen as religious - except for Trump. 27 jan. 2016a. Disponível em: <http://www.pewforum. org/2016/01/27/faith-and-the-2016-campaign/>. Access in: 10 june 2017.

How America Changed During Barack Obama's Presidency. may 2016b. Disponível em: <http://www.pewresearch.org/2017/01/10/how-america-changed-duringbarack-obamas-presidency/>. Access in: 10 june 2017.

Presidential vote by religious attendance. nov. 2016c. Disponível em: <http:// www.pewresearch.org/fact-tank/2016/11/09/how-the-faithful-voted-a-preliminary-2016analysis/ft_16-11-09_relig_exitpoll_attendance/>. Access in: 10 june 2017.

POSNER, E. A. Can It Happen Here?. Donald Trump and the Paradox of Populist Government. U of Chicago, Public Law Working Paper n. 605, 3 june 2017. Disponível em: <http://www.pewresearch.org/fact-tank/2016/11/09/how-the-faithful-voted-a-preliminary2016-analysis/ft_16-11-09_relig_exitpoll_attendance>. Access in: 10 june 2017.

REPUBLICAN PLATFORM 2016. Disponível em: <https://prod-static-ngop-pbl. s3.amazonaws.com/media/documents/DRAFT_12_FINAL[1]-ben_1468872234.pdf>. Access in: 10 june 2017.

ROTHWELL, J. T.; DIEGO-ROSELL, P. Explaining nationalist political views: The case of Donald Trump, 6 nov. 2016. Disponível em: <https://papers.ssrn.com/sol3/papers. cfm?abstract_id=2822059>. Access in: 10 june 2017.

SCHWADEL, P. Changes in American's Strength of Religious Affiliation, 1974-2010. Sociology of Religion, v. 74, n. 1, p. 107-128, 2012.

THE NEW YORK TIMES. Donald Trump's Long Record of Degrading Women. oct. 2016. Disponível em: <https://www.nytimes.com/2016/10/09/us/politics/trump-womenhistory.html>. Access in: 10 june 2017. 
Presidential Election Results: Donald J. Trump Wins. 10 fev. 2017. Disponível em: <https://www.nytimes.com/elections/results/president>. Access in: 10 june 2017.

ZURCHER, A. US Election 2016 Results: Five reasons Donald Trump won. 2016. BBC. Disponível em: <http://www.bbc.com/news/election-us-2016-37918303>. Access in: 10 june 2017.

\section{Da reação cultural e insegurança econômica na eleição presidencial estadunidense de 2016}

\section{Resumo}

Em face do forte apoio dos eleitores cristãos evangélicos à campanha presidencial de Donald Trump em 2016, muitos se questionaram sobre o modo como, exatamente, a campanha pró-religiosa de Trump conseguiu prevalecer em uma sociedade crescentemente secular. Este trabaIho contempla dois modelos conceituais, oferecidos por Ronald Inglehart e Pippa Norris, para dar algum enquadramento ao fenômeno Trump: a perspectiva da insegurança econômica e a tese da reação cultural. Cada um será considerado por meio de três conjuntos de questões relacionadas e interligadas: a direção secular geral da população estadunidense, a clivagem rural-urbano e a empatia pelos homens e pelas mulheres ignorados.

Palavras-chave: Donald Trump. Reação cultural. Insegurança econômica. Clivagem rural-urbano. Empatia. Homens e mulheres ignorados.

Recebido em: 24/01/2017.

Aprovado em: 05/04/2017. 